\title{
Asymmetric synthesis of N-protected
} \section{3-methylpiperidin-2-one and its diastereoisomer"}

\author{
Xiao-zhong $\mathrm{WANG}^{1}, \mathrm{Xia} \mathrm{WANG}^{1}$, Ying-qi $\mathrm{CHEN}^{1}$, Li-yan DAI ${ }^{\dagger+1}$, Xing-cong $\mathrm{LI}^{\dagger 2}$ \\ ( ${ }^{1}$ College of Chemical and Biological Engineering, Zhejiang University, Hangzhou 310027, China) \\ ( ${ }^{2}$ National Centers for Natural Products Research, Research Institute of Pharmaceutical Sciences, The University of Mississippi, \\ Mississippi 38677, USA) \\ †E-mail: dailiyan@zju.edu.cn; xcli7@olemiss.edu \\ Received Jan. 4, 2015; Revision accepted May 30, 2015; Crosschecked Jan. 25, 2016
}

\begin{abstract}
This paper reports the asymmetric synthesis of an important pharmaceutical intermediate (3S)-1-[(1R)-2-hydroxy-1phenylethyl]-3-methylpiperidin-2-one (compound 1) from commercially available D-plenylglycinol and delta-valerolactone. During the alkylation process, the hydroxyl group can be protected or unprotected, resulting in a different consumption of $\mathrm{s}-\mathrm{BuLi}$, and leading to a different diastereomeric excess (de) of compound 1. When 1-[(1R)-2-hydroxy-1-phenylethyl]-piperidin2-one (compound 2) was alkylated with 2.5 eq. of s-BuLi, compound 1 was obtained as a single isomer detected by chiral high performance liquid chromatography (HPLC) columns with an overall yield of $91 \%$. With the hydroxyl group protected, (R)-1(2-[(tert-butyldimethylsil) oxy]-1-phenylethyl) piperidine-2-one (compound 6) could be alkylated with 1.5 eq. of s-BuLi, giving compound $\mathbf{1}$ and its diastereoisomer $\mathbf{8}$ in a ratio of 1:2.5 and a yield of methylation of $90 \%$. Compounds $\mathbf{1}$ and $\mathbf{8}$ could be separated completely and easily by flash chromatography. The absolute configuration of compound $\mathbf{8}$ was determined by singlecrystal X-ray analysis. The mechanism of the alkylation process is discussed based on experimental results.
\end{abstract}

Key words: Asymmetric synthesis, Diastereoisomer, Hydroxyl protection group, D-plenylglycinol http://dx.doi.org/10.1631/jzus.A1500008 CLC number: TQ463

\section{Introduction}

Piperidin-2-one is a versatile building block for the synthesis of piperidine and piperidone derivatives (Bailey et al., 1998; Baussanne et al., 1998), a large variety of bioactive moieties (Kosugi et al., 2012; Wang et al., 2013; Jadav et al., 2014; Zarate et al., 2014) as well as medicines to treat diseases like inflammatory bowel disease (Old et al., 2005) and neurodegenerative diseases (Cohen and Patel, 2014). 5-substituted 1-methyl-2-pyridones, which are one kind of piperidone derivative, have been evaluated as

\footnotetext{
"Corresponding author

* Project supported by the National Natural Science Foundation of China (No. 21176213), and the Zhejiang Key Innovation Team of Green Pharmaceutical Technology (No. 2010R50043), China (6) ORCID: Xia WANG, http://orcid.org/0000-0001-8025-1309 (C) Zhejiang University and Springer-Verlag Berlin Heidelberg 2016
}

active agents against benign prostatic hyperplasia (BPH) and prostate cancer (Hartmann et al., 1994). 3, 5-disubstituted-1-methyl-4-piperidones have selective toxicity towards malignant cells and neoplasms (Pati et al., 2009). Another piperidin-2-one derivative, Sch206272, is a potent NK1/NK2 antagonist, enabling a new approach for treating asthma (Reichard et al. 2002). Because of their great potential in medical treatment, many drug companies and chemists spare no effort to develop new methods for the synthesis of piperidone derivatives. Moreover, the enantioselective synthesis of piperidone derivatives by the introduction of substituents has become an active research area (Amat et al., 2005; Castro et al., 2005). Examples include the asymmetric synthesis of 6-alkylated piperidone (Amat et al., 2003; Semak et al., 2010) and pyrrolidone (Burgess and Meyers, 1992; Meyers and Brengel, 1997). 
Methods for the preparation of enantiomerically pure piperidin-2-one derivatives have been reported by many researchers. For example, Micouin et al. (1994) prepared piperidin-2-one by reduction of oxazololactam 9. Castro et al. (2005) fabricated 3substituted piperidin-2-one by oxidation and alkylation of compound 10, and Bensa et al. (2008) synthesized piperidin-2-one by ring-opening of oxaxolidinone 11 with Grignard reagent (Scheme 1). All of these results are interesting, but the raw materials used are not easy to obtain and some of the reaction conditions are harsh. These factors make compound 2 difficult to manufacture on a large scale.

Here, we report an efficient and economical approach for the synthesis of (3S)-1-[(1R)-2-hydroxy1-phenylethyl]-3-methylpiperidin-2-one (1) or its precursor 1-[(1R)-2-hydroxy-1-phenylethyl]piperidin-2-one (2) from $\delta$-valerolactone and $\mathrm{D}$ phenylglycinol. Piperidone derivatives formed by condensation of D-plenylglycinol and oxygen containing compounds attract great interest because Dplenylglycinol is a chiral reagent that induces asymmetry (Rai and Kumar, 2013). During our process, D-phenylglycinol is protected by tertbutyldimethylsilyl chloride (TBDMS-Cl), which leads to (R)-2-[(tert-butyldimethylsilyl) oxy]-1phenyl-ethan-1-amine (5) in high enantiomeric excess. Condensation of $\mathbf{5}$ and 5-chlorovaleryl chloride gives rise to (R)-1-(2-[(tert-butyldimethyl-silyl) oxy]-1-phenylethyl) piperidin-2-one (6). Compound 6 can be alkylated directly by 1.5 eq. of s-BuLi, and ultimately compound $\mathbf{1}$ and its diastereoisomer $\mathbf{8}$ is produced in a ratio of $1: 2.5$. Alternatively, compound $\mathbf{6}$ can be transformed into compound 2 by deprotection and subsequent methylation with 2.5 eq. of s-BuLi, furnishing compound $\mathbf{1}$ as a single isomer.

\section{Methods}

\subsection{General}

All reagents were purchased from commercial sources. Absolute anhydrous tetrahydrofuran (THF) used in the alkylation reactions was prepared by distillation over natrium. $\mathrm{CH}_{2} \mathrm{Cl}_{2}$ was distilled over $\mathrm{P}_{2} \mathrm{O}_{5}$. Other reagents were used without further purification. Single-crystal structure was ascertained using a Gemini A Ultra X-ray Diffraction System from Agilent. Melting points were determined on a WRS-18 digital melting-point apparatus without correction. ${ }^{1} \mathrm{H}$ NMR spectra were recorded on a Bruker Avance DMX-500 $\mathrm{MHz}$ instrument in $\mathrm{CDCl}_{3}$ at room temperature, and chemical shifts were given in $\mathrm{ppm}$ relative to tetramethylsilane (TMS) as an internal standard $(\delta=0)$. The high resolution mass spectrum (HRMS) was obtained on GCT Premier GCTOFMA. Thin-layer chromatography (TLC) analyses were conducted on GF254 plates.

\subsection{Ethyl 5-bromopentanoate (3)}

Hydrogen bromide $(\mathrm{HBr})$ was dissolved in cold ethanol to produce $10 \%(\mathrm{w} / \mathrm{w}) \mathrm{HBr} / \mathrm{EtOH}$ solution. $\delta$-valerolactone $(1.5 \mathrm{~g}, 15 \mathrm{mmol})$ was placed into $20 \mathrm{ml} 10 \% \mathrm{HBr} / \mathrm{EtOH}$ solution in a $50 \mathrm{ml}$ reaction flask and stirred at room temperature. The reaction was monitored by TLC. After workup, $10 \mathrm{ml} \mathrm{H}_{2} \mathrm{O}$ and $10 \mathrm{ml} \mathrm{CH}_{2} \mathrm{Cl}_{2}$ were added to the mixture. The organic layer was separated, washed with brine,

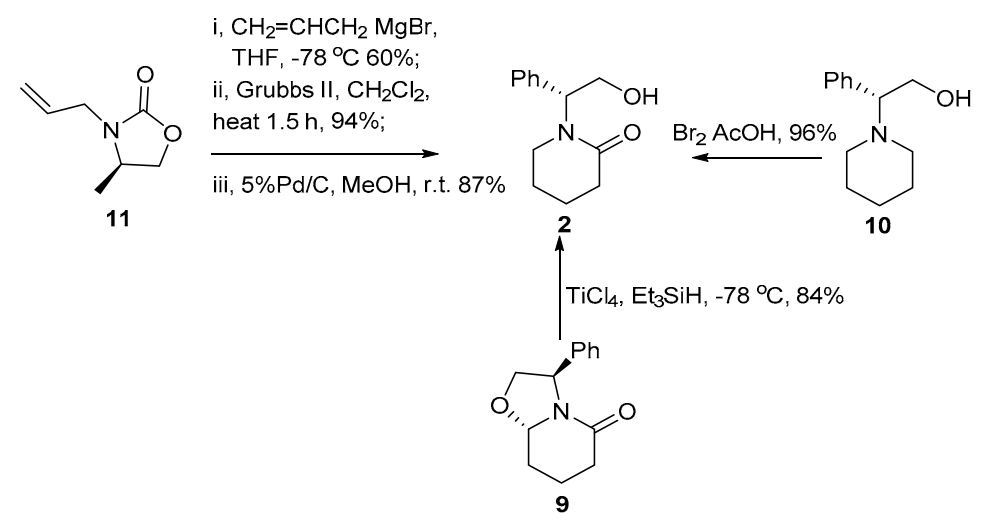

Scheme 1 Synthesis of compound 2 by the conventional method 
dried over anhydrous $\mathrm{Na}_{2} \mathrm{SO}_{4}$, and purified with flash chromatography (ethyl acetate:petroleum ether, $1: 3)$ to provide compound 3 as a colorless oil $(2.7 \mathrm{~g}$, 87\%). ${ }^{1} \mathrm{H}$ NMR: $\delta=1.26\left(\mathrm{t}, 3 \mathrm{H}, J=7, \mathrm{CH}_{3}\right), 1.79(\mathrm{~m}$, $\left.2 \mathrm{H}, \mathrm{CH}_{2}\right), 1.91\left(\mathrm{~m}, 2 \mathrm{H}, \mathrm{CH}_{2}\right), 2.34$ (t, $2 \mathrm{H}, J=7, \mathrm{CH}_{2}$ ), $3.41\left(\mathrm{t}, 2 \mathrm{H}, J=6.5, \mathrm{CH}_{2}\right)$, and $4.13\left(\mathrm{q}, 2 \mathrm{H}, J=7, \mathrm{CH}_{2}\right)$.

\subsection{3-phenyl-1,4-oxazonan-5-one (4)}

The phase transfer catalyst tetrabutyl ammonium bromide (TBAB) (0.32 g, $1 \mathrm{mmol})$, anhydrous $\mathrm{Na}_{2} \mathrm{SO}_{4}(0.85 \mathrm{~g}, 6 \mathrm{mmol})$, and $\mathrm{KOH}$ powder $(0.84 \mathrm{~g}$, $15 \mathrm{mmol})$ were added to a stirring solution of $\mathrm{D}$ phenylglycinol $(0.69 \mathrm{~g}, 5 \mathrm{mmol})$ in dry $\mathrm{CH}_{2} \mathrm{Cl}_{2}$ $(15 \mathrm{ml})$. The mixture was stirred at $-10{ }^{\circ} \mathrm{C}$ for about $15 \mathrm{~min}$ followed by addition of 5-chloropentanoyl chloride $(0.85 \mathrm{~g}, 5.5 \mathrm{mmol})$ over a period of $45 \mathrm{~min}$. When D-phenylglycinol was fully consumed (monitored by TLC), the mixture was allowed to rise to room temperature and was then stirred overnight. The mixture was then filtered. The filtrate was washed with brine, dried over anhydrous $\mathrm{Na}_{2} \mathrm{SO}_{4}$, and purified by flash chromatography (dichloromethane:methanol, 20:1) to afford compound $\mathbf{4}$ as a light yellow and viscous liquid (1.01 g, 93\%). ${ }^{1} \mathrm{H}$ NMR: $\delta=1.77\left(\mathrm{t}, J=3.5,4 \mathrm{H}, 2 \mathrm{CH}_{2}\right), 2.25(\mathrm{dt}$, $\left.J_{1}=7.4, J_{2}=3.2,2 \mathrm{H}, \mathrm{CH}_{2}\right), 3.52\left(\mathrm{~m}, 2 \mathrm{H}, \mathrm{CH}_{2}\right), 3.81$ $\left(\mathrm{m}, 2 \mathrm{H}, \mathrm{CH}_{2}\right), 5.03\left(\mathrm{td}, J_{1}=6.5, J_{2}=4.4, J=5.5,1 \mathrm{H}\right.$, $\mathrm{CH}), 6.58(\mathrm{~d}, J=7,1 \mathrm{H}, \mathrm{NH})$, and $7.3\left(\mathrm{~m}, 5 \mathrm{H}, \mathrm{C}_{6} \mathrm{H}_{5}\right)$. HRMS: 219.1254 (calculated value: 219.1259).

\section{$2.4 \quad$ (R)-2-[(tert-butyldimethylsilyl) oxy]-1- phenyl-ethan-1-amine (5)}

$\mathrm{Et}_{3} \mathrm{~N}$ (4.1 ml, $\left.29.2 \mathrm{mmol}\right)$ and 4-dimethylaminopyridine (DMAP) (0.35 g, $2.9 \mathrm{mmol})$ were added to a stirring solution of D-phenylglycinol (2 $\mathrm{g}$, $14.6 \mathrm{mmol})$ in dry $\mathrm{CH}_{2} \mathrm{Cl}_{2}(15 \mathrm{ml})$. The mixture was stirred at $0{ }^{\circ} \mathrm{C}$ for $10 \mathrm{~min}$, then TBDMS-Cl $(2.34 \mathrm{~g}$, $15.3 \mathrm{mmol}$ ), dissolved in $15 \mathrm{ml} \mathrm{CH} \mathrm{Cl}_{2}$, was added dropwise. The mixture was stirred at room temperature for $18 \mathrm{~h}$, quenched with $\mathrm{H}_{2} \mathrm{O}(10 \mathrm{ml})$, washed with brine and extracted with $\mathrm{CH}_{2} \mathrm{Cl}_{2}$. The combined organic layer was concentrated under vacuum and the residue was purified by flash chromatography (ethyl acetate:petroleum ether, 1:3) to provide compound 5 as a light yellow oil ( $3 \mathrm{~g}, 82 \%) .{ }^{1} \mathrm{H}$ NMR: $\delta=0.02\left(\mathrm{~s}, 6 \mathrm{H}, 2 \mathrm{CH}_{3}\right), 0.90\left(\mathrm{~s}, 9 \mathrm{H}, \mathrm{C}\left(\mathrm{CH}_{3}\right)_{3}\right), 1.82(\mathrm{~s}$, $\left.2 \mathrm{H}, \mathrm{NH}_{2}\right), 3.52\left(\mathrm{dd}, J_{1}=9.5, J_{2}=8.5,1 \mathrm{H}\right.$ of $\left.\mathrm{CH}_{2}, \mathrm{AB}\right)$, $3.72\left(\mathrm{dd}, J_{1}=10, J_{2}=4,1 \mathrm{H}\right.$ of $\left.\mathrm{CH}_{2}, \mathrm{AB}\right), 4.07(\mathrm{dd}$, $\left.J_{1}=8.4, J_{2}=4,1 \mathrm{H}, \mathrm{CH}\right)$, and 7.26-7.38 (m, 5H, $\left.\mathrm{C}_{6} \mathrm{H}_{5}\right)$.

\section{5 (R)-1-(2-[(tert-butyldimethylsilyl) oxy]-1- phenylethyl) piperidin-2-one (6)}

Silyl ethers 5 (20 g, $80 \mathrm{mmol})$ and TBAB $(5.15 \mathrm{~g}, 16 \mathrm{mmol})$ were dissolved in dry $\mathrm{CH}_{2} \mathrm{Cl}_{2}$ $(60 \mathrm{ml})$. The mixture was stirred at $-10{ }^{\circ} \mathrm{C}$ for $10 \mathrm{~min}$. KOH powder $(13.4 \mathrm{~g}, 240 \mathrm{mmol})$ and 5 chloropentanoyl chloride $(12.4 \mathrm{~g}, 80 \mathrm{mmol})$ were added to the reaction mixture in three batches, consecutively. Then the mixture was stirred at $-2{ }^{\circ} \mathrm{C}$ for about $1 \mathrm{~h}$. After consumption of $\mathbf{5}$, the mixture was warmed up to room temperature, stirred overnight and then filtered. The filtrate was adjusted to about pH7 using acetic acid. The organic liquid was dried over $\mathrm{Na}_{2} \mathrm{SO}_{4}$, concentrated under vacuum, and purified by recrystallization or flash chromatography (petroleum ether:acetic ether, 3:1) to provide $24 \mathrm{~g}$ (90\%) of compound 6 as a white solid (Mp: 62.4$63.7{ }^{\circ} \mathrm{C}$ ). ${ }^{1} \mathrm{H}$ NMR: $\delta=0.09\left(\mathrm{~s}, 6 \mathrm{H}, 2 \mathrm{CH}_{3}\right), 0.88$ (s, $\left.9 \mathrm{H}, \mathrm{C}\left(\mathrm{CH}_{3}\right)_{3}\right), 1.63-1.78\left(\mathrm{~m}, 4 \mathrm{H}, 2 \mathrm{CH}_{2}\right), 2.45-2.51$ $\left(\mathrm{td}, J_{1}=6.9, J_{2}=2.0,2 \mathrm{H}, \mathrm{CH}_{2}\right), 2.98-3.02$ (ddd, $J_{1}=12.0, J_{2}=6.0, J_{3}=4.1,1 \mathrm{H}$ of $\mathrm{CH}_{2}$ ), 3.26-3.31 (ddd, $J_{1}=12.0, J_{2}=8.0, J_{3}=4.1,1 \mathrm{H}$ of $\left.\mathrm{CH}_{2}\right), 4.1(\mathrm{~d}, J=6.5$, $\left.2 \mathrm{H}, \mathrm{CH}_{2}\right), 5.88(\mathrm{t}, J=6.5,1 \mathrm{H}, \mathrm{CH})$, and $7.26-7.33(\mathrm{~m}$, $5 \mathrm{H}, \mathrm{C}_{6} \mathrm{H}_{5}$ ).

\subsection{1-[(1R)-2-hydroxy-1-phenylethyl]-piperidin- 2-one (2)}

Compound 6 (3.3 g, $10 \mathrm{mmol})$ was added to $20 \mathrm{ml}$ of $1 \%-2 \%(\mathrm{w} / \mathrm{w}) \mathrm{HCl} / \mathrm{EtOH}$ solution, stirred at room temperature for half an hour, and then quenched by addition of saturated $\mathrm{NaHCO}_{3}$. The residue was extracted by $\mathrm{CH}_{2} \mathrm{Cl}_{2}$ and purified by chromatography (acetic ether:dichloromethane, 15:1) or recrystallization, resulting in compound $\mathbf{2}$ as a white crystal $(2 \mathrm{~g}, 91 \%)$. $[\alpha] \mathrm{D}^{19}-75.2\left(c=0.5, \mathrm{CHCl}_{3}\right)$, Mp: $109-110.5{ }^{\circ} \mathrm{C} .{ }^{1} \mathrm{H}$ NMR: $\delta=1.66-1.80(\mathrm{~m}, 4 \mathrm{H}$, $2 \mathrm{CH}_{2}$ ), 2.49-2.51 (dq, $J_{1}=6.7, J_{2}=3.7,2 \mathrm{H}, \mathrm{CH}_{2}$ ), 2.93-2.97 (m, $2 \mathrm{H}, 1 \mathrm{H}$ of $\mathrm{CH}_{2}$ and $1 \mathrm{H}$ of $\left.\mathrm{OH}\right), 3.18$ 3.23 (ddd, $J_{1}=12, J_{2}=7.7, J_{3}=3.8,1 \mathrm{H}$ of $\mathrm{CH}_{2}$ ), 4.094.16 (qd, $\left.J_{1}=11.5, J_{2}=7,2 \mathrm{H}, \mathrm{CH}_{2}\right), 5.79-5.81(\mathrm{dd}$, $\left.J_{1}=9, J_{2}=5,1 \mathrm{H}, \mathrm{CH}\right)$, and 7.24-7.36 (m, $\left.5 \mathrm{H}, \mathrm{C}_{6} \mathrm{H}_{5}\right)$.

To determine the structure more precisely, we made compound 2 react with $\mathrm{D}_{2} \mathrm{O} .{ }^{1} \mathrm{H}$ NMR showed that the hydrogen of the hydroxyl group disappeared.

\section{7 (3S)-1-[(R)-2-hydroxy-1-phenylethyl]-3- methylpiperidin-2-one (1)}

s-BuLi (55 ml, $70.1 \mathrm{mmol}, 2.5$ eq.) was added to a solution of lactam $2(6.2 \mathrm{~g}, 28.3 \mathrm{mmol})$ in THF 
(75 ml) under nitrogen at $-78{ }^{\circ} \mathrm{C}$. The mixture was stirred for $30 \mathrm{~min}$ and $\mathrm{MeI}(5.5 \mathrm{ml}, 85 \mathrm{mmol}, 3.0$ eq.) was added slowly. It was then stirred at $-78{ }^{\circ} \mathrm{C}$ for $3 \mathrm{~h}$. Afterwards, $60 \mathrm{ml}$ saturated $\mathrm{NH}_{4} \mathrm{Cl}$ was added and the mixture was allowed to rise to room temperature. The organic layer was separated and the residue was extracted by $\mathrm{CH}_{2} \mathrm{Cl}_{2}(2 \mathrm{ml} \times 3)$. The organic phases were combined, washed with brine and concentrated. White solid was obtained after crystallization from acetic ether $(6.1 \mathrm{~g}, 91 \%)$, Mp: 117.3$118.4{ }^{\circ} \mathrm{C} .{ }^{1} \mathrm{H}$ NMR: $\delta=1.26\left(\mathrm{~d}, J=7.5,3 \mathrm{H}, \mathrm{CH}_{3}\right)$, $1.42-1.48\left(\mathrm{~m}, 1 \mathrm{H}\right.$ of $\left.\mathrm{CH}_{2}\right), 1.68-1.73(\mathrm{p}, J=6.3,2 \mathrm{H}$, $\left.\mathrm{CH}_{2}\right), 1.91-1.96\left(\mathrm{~m}, 1 \mathrm{H}\right.$ of $\left.\mathrm{CH}_{2}\right), 2.04(\mathrm{~s}, 2 \mathrm{H}, 1 \mathrm{H}$ of $\mathrm{OH}$ and $1 \mathrm{H}$ of $\left.\mathrm{H}_{2} \mathrm{O}\right), 2.52-2.56(\mathrm{~m}, 1 \mathrm{H}, \mathrm{CH}), 2.88-$ $2.93\left(\mathrm{dt}, J_{1}=12.5, J_{2}=6,1 \mathrm{H}\right.$ of $\left.\mathrm{CH}_{2}, \mathrm{AB}\right), 3.20-3.25$ (dt, $J_{1}=12.0, J_{2}=6,1 \mathrm{H}$ of $\left.\mathrm{CH}_{2}, \mathrm{AB}\right), 4.06-4.16(\mathrm{~m}$, $\left.2 \mathrm{H}, \mathrm{CH}_{2}\right)$, and $7.23-7.33\left(\mathrm{~m}, 5 \mathrm{H}, \mathrm{C}_{6} \mathrm{H}_{5}\right)$.

\section{$2.8 \quad 1-((\mathbf{R})-2-[($ tert-butyldimethylsilyl) $\quad 0 x y]-1-$ phenylethyl)-3-methylpiperidin-2-one (7)}

s-BuLi $2.3 \mathrm{ml}$ ( $3 \mathrm{mmol}, 1.5$ eq.) was added to a solution of lactam $6(0.67 \mathrm{~g}, 2 \mathrm{mmol})$ in absolute THF $(20 \mathrm{ml})$ under nitrogen at $-78{ }^{\circ} \mathrm{C}$. MeI $0.37 \mathrm{ml}$ (6 mmol, 3.0 eq.) was added slowly. After stirring at $-78{ }^{\circ} \mathrm{C}$ for $3 \mathrm{~h}, 10 \mathrm{ml}$ saturated $\mathrm{NH}_{4} \mathrm{Cl}$ was added and the mixture was allowed to rise to room temperature. The organic layer was separated and the residue was extracted using $\mathrm{CH}_{2} \mathrm{Cl}_{2}$. The organic phases were combined, washed with brine and concentrated. The residue was purified by flash chromatography (ethyl acetate:petroleum ether, 1:3), giving light yellow crystals $0.62 \mathrm{~g}(90 \%), \mathrm{Mp}: 77.3-78.4{ }^{\circ} \mathrm{C}$. ${ }^{1} \mathrm{H}$ NMR: $\delta=0.08 \quad\left(\mathrm{~s}, 6 \mathrm{H}, 2 \mathrm{CH}_{3}\right), 0.89(\mathrm{~s}, 9 \mathrm{H}$, $\left.\mathrm{C}\left(\mathrm{CH}_{3}\right)_{3}\right), 1.28\left(\mathrm{~d}, J=7.5,3 \mathrm{H}, \mathrm{CH}_{3}\right), 1.44-1.97(\mathrm{~m}$, $\left.4 \mathrm{H}, 2 \mathrm{CH}_{2}\right), 2.48(\mathrm{~m}, 1 \mathrm{H}, \mathrm{CH}), 3.0\left(\mathrm{~m}, 1 \mathrm{H}\right.$ of $\left.\mathrm{CH}_{2}\right)$, $3.29\left(\mathrm{~m}, 1 \mathrm{H}\right.$ of $\left.\mathrm{CH}_{2}\right), 4.08-4.11\left(\mathrm{~m}, 2 \mathrm{H}, \mathrm{CH}_{2}\right), 5.8-$ $5.9\left(\mathrm{dt}, J_{1}=40.7, J_{2}=6.5,1 \mathrm{H}, \mathrm{CH}\right)$, and $7.3(\mathrm{~m}, 5 \mathrm{H}$, $\mathrm{C}_{6} \mathrm{H}_{5}$ ). HRMS: 347.2285 (calculated value: 347.2281).

\subsection{Crystal structure of compound 8}

Compound 8 comprised colorless crystals, $0.39 \mathrm{~mm} \times 0.36 \mathrm{~mm} \times 0.28 \mathrm{~mm}, \mathrm{C}_{14} \mathrm{H}_{21} \mathrm{NO}_{3}$, orthorhombic, $a=6.457$ (19), $b=9.92$ (3), $c=21.99$ (8) $(\times 0.1 \mathrm{~nm}), V=1408.84(8) \times(0.1 \mathrm{~nm})^{3}, \mathrm{~F}(000)=544$, $Z=4, \rho=1.185 \mathrm{~g} / \mathrm{cm}^{3}$, space group $\mathrm{P} 2{ }_{1} 2_{1} 2_{1}$. A set of 2497 reflections was collected at $T=293 \mathrm{~K}$. The transmission factor was in the range of $0.827-1.000$. All measurements were made using an enhanced ultra $(\mathrm{Cu}-\mathrm{Ka}, \lambda=1.54184 \times 0.1 \mathrm{~nm}) \mathrm{X}$-ray generator. $R_{1}=0.0495$ and $\mathrm{wR}_{2}=0.1424, S=0.157$. The structure was solved by SHELXS and refined with SHELXL. Structural factors and raw data files are available on request from the authors.

\section{Results and discussion}

We previously followed the procedure for a similar reaction as described by Philippe et al. (1996; 2000). Difficulties were encountered in the preparation of lactam 2. Treatment of $\delta$-valerolactone with $\mathrm{HBr} / \mathrm{EtOH}$ gave rise to ethyl 5-bromopentanoate (3), but attempts to condense compound 3 with Dplenylglycinol gave no six-membered ring lactam (Scheme 2). We attributed this phenomenon to the lower activity of compound $\mathbf{3}$.

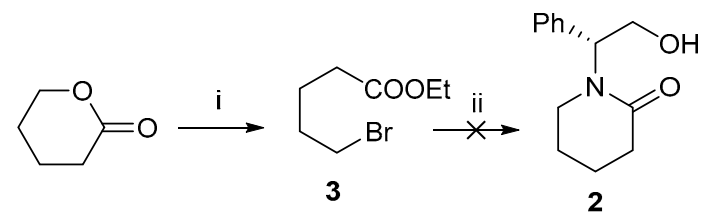

Scheme 2 Synthesis of compound 2 via compound 3 i: $\mathrm{HBr} / \mathrm{EtOH}$; ii: $\mathrm{K}_{2} \mathrm{CO}_{3}$, EtOH, D-plenylglycinol, reflux

Thus, ethyl 5-bromopentanoate was replaced by 5-chlorovaleryl chloride which has better activity. Then, treatment of $\delta$-valerolactone with thionyl chloride gave rise to 5-chlorovaleryl chloride. 5chloropentanoyl chloride was then condensed with D-phenylglycinol in the presence of TBAB. After workup, we obtained a compound as a light yellow and viscous liquid. According to the ${ }^{1} \mathrm{H}$ NMR and HRMS spectra, we confirmed that the product was compound $\mathbf{4}$, rather than compound $\mathbf{2}$ which we had expected to obtain (Scheme 3).

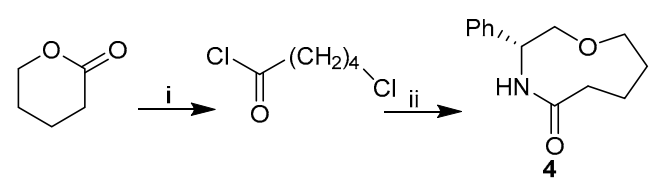

Scheme 3 Attempts to synthesize hexatomic ring lactam i: $\mathrm{SOCl}_{2}$, reflux; ii: TBAB, $\mathrm{KOH}, \mathrm{Na}_{2} \mathrm{SO}_{4}$, D-plenylglycinol, $-10{ }^{\circ} \mathrm{C}$ to room temperature

From Scheme 3 we concluded that the hydroxyl group was more reactive than amide. To avoid formation of compound $\mathbf{4}$, the hydroxyl group should be protected. Here, TBDMS-Cl was introduced to 
form steady silyl ether 5 (Isobe et al., 2000). Condensation of compound $\mathbf{5}$ and 5-chloropentanoyl chloride led successfully to lactam $\mathbf{6}$ as a white powder. The hydroxyl group was then deprotected in a $1 \%-2 \%$ concentration of $\mathrm{HCl} / \mathrm{EtOH}$, affording 2 as a white powder (Scheme 4). ${ }^{1} \mathrm{H}$ NMR showed that compound 2's structure was the same as reported in the literature (Castro et al., 2005; Bensa et al., 2008). Furthermore, to determine the configuration of $\mathbf{2}$, we synthesized the racemate of $\boldsymbol{2}$ with D/Lphenylglycinol. The racemate of $\mathbf{2}$ was separated sharply by chiral HPLC columns (OJ-3) using $n$ hexane and isopropanol (90:10) as the mobile phase. With the same conditions, the enantiomeric excess value (ee) of compound $\mathbf{2}$ was confirmed to be greater than $98 \%$ (Fig. 1).
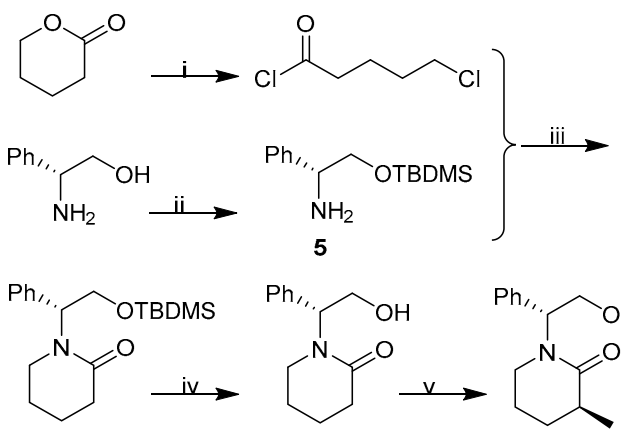

6

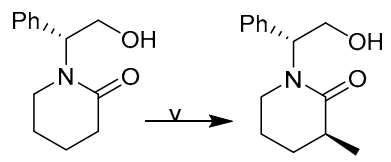

2

1

Scheme 4 Synthesis of compound 1

i: $\mathrm{SOCl}_{2}$, reflux; ii: DMAP, $\mathrm{Et}_{3} \mathrm{~N}, \mathrm{TBDMSCl}$; iii: $\mathrm{TBAB}$, $\mathrm{KOH},-10{ }^{\circ} \mathrm{C}$ to $-2{ }^{\circ} \mathrm{C},-2{ }^{\circ} \mathrm{C}$ to room temperature; iv: $\mathrm{HCl} / \mathrm{EtOH}$; v: $\mathrm{CH}_{3} \mathrm{I}, 2.5$ eq. s-BuLi, $-78^{\circ} \mathrm{C}$

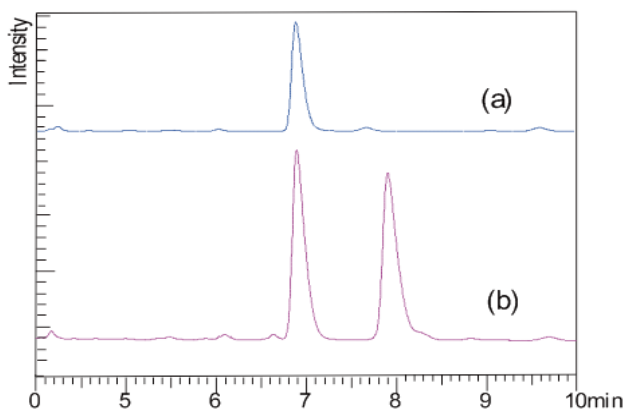

Fig. 1 Comparison of compound 2 and its recamate: (a) compound 2; (b) recamate of compound 2

Compound 2 was then methylated, furnishing compound 1 with no less than $98 \%$ diastereoisomeric excess (de) value (Fig. 2a). The racemate of compound 1 (Fig. 2b) was also synthesized for comparison, to ascertain the de value of compound 1 .

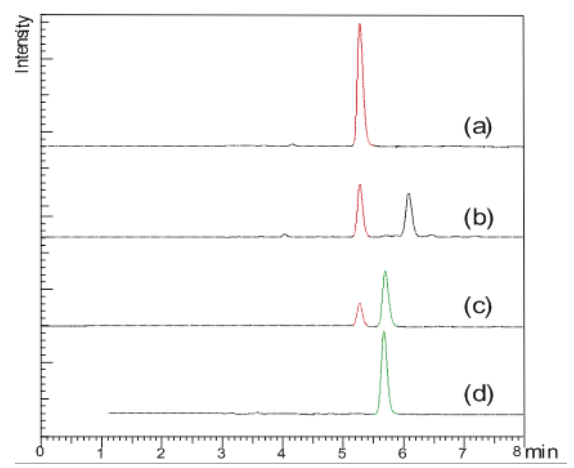

Fig. 2 HPLC of final products: (a) compound 1; (b) racemate of compound 1; (c) deprotection of compound 7; (d) compound 8

Considering that when compound $\mathbf{2}$ was alkylated, the hydroxyl group would consume 1 eq. of s$\mathrm{BuLi}$, and s-BuLi is both dangerous and expensive, we decided to use alkylate 6 with 1.5 eq. of s-BuLi. After methylation and deprotection (Scheme 5), the separated product was detected by HPLC. According to HPLC spectra, compound $\mathbf{1}$ was not the main product (Fig. 2c). The mixture was then separated by flash chromatography and the main product was characterized by ${ }^{1} \mathrm{H}$ NMR. The results showed that it had the same structure as product $\mathbf{1}$, while HPLC confirmed that it was not one of compound 1's racemates (Fig. 2d). Since the configuration of Dplenylglycinol would not change, we speculated that the main product was the diastereoisomer of compound 1. This compound was crystallized from ethyl acetate, and single-crystal X-ray analysis was used to determine its absolute configuration (Fig. 3).

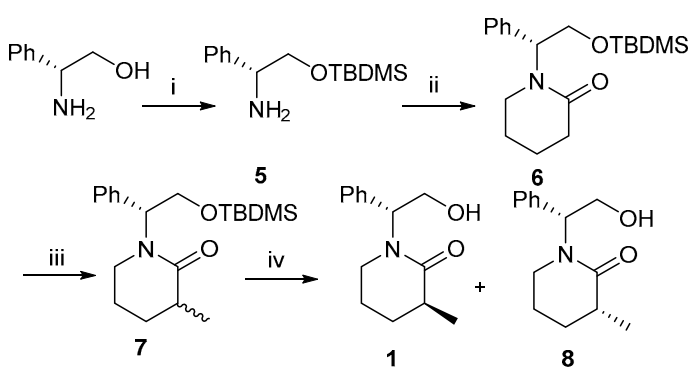

Scheme 5 Synthesis of compound 1 and its racemate i: DMAP, $\mathrm{Et}_{3} \mathrm{~N}, \mathrm{TBDMSCl}$; ii: TBAB, $\mathrm{KOH}, 5$-chloropentanoyl chloride, $-10{ }^{\circ} \mathrm{C}$ to $-2{ }^{\circ} \mathrm{C},-2{ }^{\circ} \mathrm{C}$ to room temperature; iii: $\mathrm{CH}_{3} \mathrm{I}, 1.5$ eq. $\mathrm{s}-\mathrm{BuLi},-78^{\circ} \mathrm{C}$; iv: $\mathrm{HCl} / \mathrm{EtOH}$

Accordingly, deprotection of compound 7 gave a mixture of compound $\mathbf{1}$ and its diastereoisomer $\mathbf{8}$ in a ratio of about 1:2.5. However, compounds $\mathbf{1}$ and $\mathbf{8}$ could be separated easily by column chromatography 
or recrystallization with both de values greater than $99 \%$.

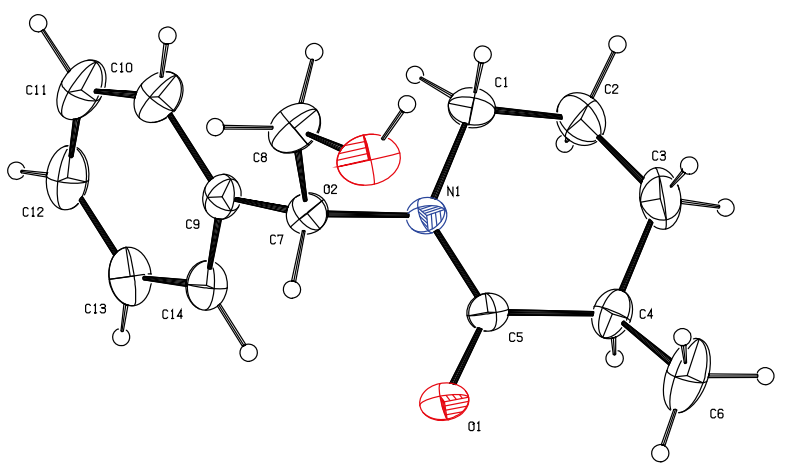

Fig. 3 Crystal structure of compound 8

The mechanism underlying the efficient diastereoselective alkylation of compound $\mathbf{2}$ can be explained by a chelation process described by Laube $e t$ al. (1985). Nitrogen hybridization in compound $\mathbf{2}$ is $\mathrm{sp}^{3}$ and nitrogen is known to be highly pyramidalized in amide enolates, which can be excellent electron donors allowing chelation with $\mathrm{Li}^{+}$. This effect forms an $\alpha$-face blocking group that makes the alkylation progress in the less hindered face just like compound I (Fig. 4). This explanation is supported by Micouin (1994) and our experimental results.

When the hydroxyl group is protected by the silicon group, the five-numbered blocking group cannot generate successfully like compound I and the chelation effect between $\mathrm{N}$ and $\mathrm{Li}^{+}$disappears. Furthermore, the molecular configuration of compound 8 adopts the lowest interatomic force through free rotation of the atoms, which satisfies the lowest energy principle in molecular structure. Because of this, the big t-butyldimethylsilyl group turns away from nitrogen and becomes a $\beta$-face blocking group. Hence, the $\alpha$-face is much easier to attack like II. As a result, compound $\mathbf{8}$ becomes the main product. Our discovery can also be explained by Wuensch and Meyers (1990)'s experiment, in which the silicon group does not chelate with the nitrogen atom, but turns away from it completely because of dipoledipole repulsion.
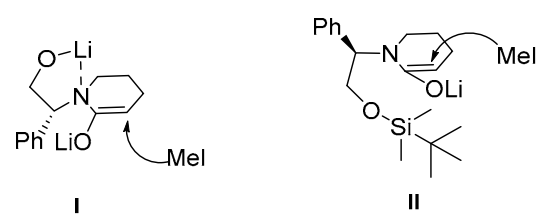

Fig. 4 Different steric configurations of methylation

\section{Conclusions}

In summary, we have developed an efficient method for the asymmetric synthesis of high purity (3S)-1-[(1R)-2-hydroxy-1-phenylethyl]-3-methylpiperidin-2-one (1) with D-plenylglycinol and deltavalerolactone as raw materials. Moreover, we have explored a method for the alkylation of (R)-1-[2[(tert-butyldimethylsilyl) oxy]-1-phenylethyl]piperidin -2-one (6) using less s-BuLi to produce enantiomerically pure compound $\mathbf{1}$ and its diastereoisomer (3R)1-[(R)-2-hydroxy-1-phenylethyl]-3-methylpiperidin2-one (8). As far as we know, this is the first time that compounds $\mathbf{4}, \mathbf{7}$, and $\mathbf{8}$ have been synthesized and analyzed.

As there are lots of hydroxyl protected groups, and different groups have different sizes and special configurations, we will continue to study how different hydroxyl protecting groups affect the stereoselectivity of the alkylation process.

\section{References}

Amat, M., Llor, N., Hidalgo, J., et al., 2003. Enantioselective synthesis of piperidine, indolizidine, and quinolizidine alkaloids from a phenylglycinol-derived $\delta$-lactam. The Journal of Organic Chemistry, 68(5):1919-1928. http://dx.doi.org/10.1021/jo0266083

Amat, M., Escolano, C., Llor, N., et al., 2005. Alkylation of phenylglycinol-derived bicyclic lactams. Enantioselective synthesis of 3-alkylpiperidines. Archive for Organic Chemistry, 2005(9):115-123.

http://dx.doi.org/10.3998/ark.5550190.0006.912

Bailey, P.D., Millwood, P.A., Smith, P.D., 1998. Asymmetric routes to substituted piperidines. Chemical Communications, (6):633-640.

http://dx.doi.org/10.1039/a709071d

Baussanne, I., Travers, C., Royer, J., 1998. Asymmetric synthesis of 3-substituted pyrrolidones via [alpha]alkylation of a chiral non-racemic [gamma]-lactam. Tetrahedron: Asymmetry, 9(5):797-804. http://dx.doi.org/10.1016/S0957-4166(98)00024-X

Bensa, D., Coldham, I., Feinäugle, P., et al., 2008. Synthesis of carboxylic amides by ring-opening of oxazolidinones with Grignard reagents. Organic \& Biomolecular Chemistry, 6(8):1410-1415. http://dx.doi.org/10.1039/b800849c

Burgess, L.E., Meyers, A., 1992. A simple asymmetric synthesis of 2-substituted pyrrolidines and 5-substituted pyrrolidinones. The Journal of Organic Chemistry, 57(6): 1656-1662. http://dx.doi.org/10.1021/jo00032a012

Castro, C.A., Juárez, P.J., Gnecco, D., et al., 2005. Efficient preparation of (1'R)-(-)-1-(2'-hydroxy-1'-phenylethyl) 
piperidin-2-one: synthesis of (2'S,3R)-(+)-stenusine. Tetrahedron: Asymmetry, 16(5):949-952. http://dx.doi.org/10.1016/j.tetasy.2005.01.023

Cohen, F., Patel, S., 2014. Preparation of C-linked Heterocycloalkyl Substituted Pyrimidines as Inhibitors of DLK Useful for Treating Neurodegeneration Diseases and Disorders. WO Patent 2014177524.

Hartmann, R.W., Reichert, M., Göhring, S., 1994. Novel 5alpha-reductase inhibitors-synthesis and structureactivity studies of 5-substituted 1-methyl-2-pyridones and 1-methyl-2-piperidones. European Journal of Medicinal Chemistry, 29(11):807-817. http://dx.doi.org/10.1016/0223-5234(94)90104-X

Isobe, T., Fukuda, K., Ishikawa, T., 2000. Modified guanidines as potential chiral superbases. 3. Preparation of 1,4,6-triazabicyclooctene systems and 1,4-disubstituted 2-iminoimidazolidines by the 2-chloro-1,3dimethylimidazolinium chloride-induced cyclization of guanidines with a hydroxyethyl substituent. The Journal of Organic Chemistry, 65(23):7779-7785.

Jadav, P., Bahekar, R., Shah, S.R., et al., 2014. Design, synthesis and biological evaluation of novel aminomethylpiperidones based DPP-IV inhibitors. Bioorganic \& Medicinal Chemistry Letters, 24(8):1918-1922. http://dx.doi.org/10.1016/j.bmcl.2014.03.009

Kosugi, T., Mitchell, D.R., Fujino, A., et al., 2012. Mitogenactivated protein kinase-activated protein kinase 2 (mapkap-k2) as an antiinflammatory target: discovery and in vivo activity of selective pyrazolo[1,5-a]pyrimidine inhibitors using a focused library and structure-based optimization approach. Journal of Medicinal Chemistry, 55(15):6700-6715. http://dx.doi.org/10.1021/jm300411k

Laube, T., Dunitz, J.D., Seebach, D., 1985. On the interaction between lithium enolates and secondary-amines in solution and in the crystal. Helvetica Chimica Acta, 68(5): 1373-1393. http://dx.doi.org/10.1002/hlca.19850680530

Meyers, A.I., Brengel, G.P., 1997. Chiral bicyclic lactams: useful precursors and templates for asymmetric syntheses1. Chemical Communications, 1997(1):1-8. http://dx.doi.org/10.1039/a604443c

Micouin, L., Varea, T., Quirion, J.C., et al., 1994. Asymmetric synthesis, XXX, synthesis of 3-substituted piperidines from chiral non-racemic lactams. Tetrahedron Letters, 35(16):2529-2532. http://dx.doi.org/10.1016/S0040-4039(00)77162-0

Old, D.W., Dinh, D.T., Kedzie, K.M., et al., 2005. Treatment of Inflammatory Bowel Disease with Prostaglandin Piperidine Analogs. US Patent 20050171062.

Pati, H.N., Das, U., Das, S., et al., 2009. The cytotoxic properties and preferential toxicity to tumour cells displayed by some 2,4-bis(benzylidene)-8-methyl-8-azabicyclo [3.2.1] octan-3-ones and 3,5-bis(benzylidene)-1-methyl4-piperidones. European Journal of Medicinal Chemistry, 44(1):54-62.

http://dx.doi.org/10.1016/j.ejmech.2008.03.015
Philippe, N., Levacher, V., Dupas, G., et al., 1996. Diastereoselective alkylation of homochiral 1,2,3,4tetrahydroisoquinolin-3-one. A potential route to enantiomerically pure 4-substituted tetrahydroisoquinolines. Tetrahedron: Asymmetry, 7(2):417-420. http://dx.doi.org/10.1016/0957-4166(96)00022-5

Philippe, N., Levacher, V., Dupas, G., et al., 2000. Diastereoselective protonation of lactam enolates derived from (R)-phenylglycinol. A novel asymmetric route to 4phenyl-1,2,3,4-tetrahydroisoquinolines. Organic Letters, 2(15):2185-2187. http://dx.doi.org/10.1021/o10057939

Rai, B., Kumar, A., 2013. Synthesis, characterization and biocidal activity of some Schiff base and its metal complexes of Co (II), Cu (II) and Ni (II). Oriental Journal of Chemistry, 29(3):1187-1191. http://dx.doi.org/10.13005/ojc/290349

Reichard, G.A., Grice, C.A., Shih, N.Y., et al., 2002. Preparation of oxime dual $\mathrm{NK}_{1} / \mathrm{NK}_{2}$ antagonists with reduced $\mathrm{NK}_{3}$ affinity. Bioorganic \& Medicinal Chemistry Letters, 12(17):2355-2358. http://dx.doi.org/10.1016/S0960-894X(02)00462-6

Semak, V., Escolano, C., Arróniz, C., et al., 2010. A practical procedure for the removal of the phenylethanol moiety from phenylglycinol-derived lactams. Tetrahedron: Asymmetry, 21(20):2542-2549. http://dx.doi.org/10.1016/j.tetasy.2010.09.014

Wang, Y., Zhang, Y., Zheng, L., et al., 2013. Four new alkaloids from the fermentation broth of armillaria mellea. Helvetica Chimica Acta, 96(2):330-337. http://dx.doi.org/10.1002/hlca.201200186

Wuensch, T., Meyers, A., 1990. Asymmetric synthesis of 4,4disubstituted 1-naphthalenones. Diastereoselectivity as a function of metal alkoxides. The Journal of Organic Chemistry, 55(14):4233-4235. http://dx.doi.org/10.1021/jo00301a002

Zarate, A., Orea, L., Juarez, J.R., et al., 2014. Diastereoselective approach to $c i s-4$-methyl/thiol-pipecolic esters based on RCM reaction and conjugate Michael addition. Synthetic Communications, 44(19):2838-2847. http://dx.doi.org/10.1080/00397911.2014.918147

\section{中文概要}

题 目：(3S)-1- $[(\mathrm{R})-2$-羟基-1-苯乙基]-3-甲基-2-哌啶酮的 合成

目 的：探索合成(3S)-1-[(R)-2-羟基-1-苯乙基]-3-甲基-2哌啶酮的新方法。

创新点: 以常规化工原料 D-苯苷氨醇为主要原料, 在比 较温和的条件下合成重要的药物中间体(3S)-1[(R)-2-差基-1-苯乙基]-3-甲基-2-哌啶酮及其同系 物。该方法中的甲基化步骤较常规甲基化步骤 减少 1 当量 $\mathrm{s}-\mathrm{BuLi}$ 的用量, 更环保和安全。 
方 法：利用 D-苯苷氨醇的空间位阻作用, 在六元环内 酰胺中引入具有特定光学纯度的手性甲基。在 甲基化过程中，用叔丁基二甲基氯硅烷对羟基 进行保护, 以减少仲丁基锂的用量。

结 论：以工业易得的 $\delta$-戊内酯及 $\mathrm{D}$-苯苷氨醇为初始原 料, 探索合成 3-甲基-2-哌啶酮类物质的新方 法。新方法中对仲丁基锂的消耗量与常规方法 有所不同。当着基受保护时，甲基化 1 当量六 元环内酰胺 (化合物 7) 消耗 1.5 当量而非 2.5
当量仲丁基锂, 甲基化产物脱掉醇羟基保护 基, 得到(3S)-1-[(R)-2-羟基-1-苯乙基]-3-甲基-2哌啶酮（化合物 1) 及其非对映异构体(3R)-1[(R)-2-羟基-1-苯乙基]-3-甲基-2-哌啶酮（化合物 8), 二者摩尔比为 1:2.5。通过重结晶或柱层析 的方法可对二者进行完全分离。

关键词：哌啶酮; 生物碱; 不对称合成; D-苯甘氨醇; 醇羟基保护基 